\title{
Diplomasi dili ve çevirisi
}

\section{Gülhanım ÜNSAL ${ }^{1}$}

APA: Ünsal, G. (2019). Diplomasi dili ve çevirisi. RumeliDE Dil ve Edebiyat Araştırmaları Dergisi, (17), 22-39. DOI: 10.29000/rumelide.656595.

\section{Öz}

Farklı toplumlar arasında ilişki kurmaya yarayan diplomasi, Devletlerin dış politika araçlardan biri olarak tanımlanır. Eski ve yeni olmak üzere, ad hoc, sürekli, gizli, kapalı, açık vb. pek çok türü vardır. Günümüzde diplomasi diplomatlar aracılı̆̆ıyla yürütülür. Diplomasi dili biçimsel bir dildir, belli kalıpları vardır. Siyaset dilinin bir parçasıdır. Diplomasi dili uzmanlık dili; teknik terim ve ifadeler; müzakere dili olmak üzere üçe ayrılır. Yazılı ve sözlü pek çok metin türü bulunur. Diplomasi ikna etme sanatı olduğu için dilin çağrı işlevine başvurur. Diplomasi dilinde eğretileme, düzdeğişmece, kapsamlayış, dolaylama, benzetme, arıksayış, örtmece, kişileştirme, üçlü dizem vb. söz sanatlarına rastlanır. Bu çalışmanın amacını, diplomasi dilinin biçimsel, anlamsal ve kültürel özelliklerini incelemek, diplomasi çevirisinde karşılaşılan sorunları ve çeviri stratejilerini belirlemek oluşturmaktadır. Çalışmanın yöntemi betimsel bir nitelik taşımaktadır. Bu bağlamda, T. C. Dışişleri Bakanlığı'nın basın bildirilerinden alınan metinler erek dilde çevirmen kararları doğrultusunda incelenmiştir. İnceleme metinleri "saldırı, kaza, vefat bağlamında yazılan taziye mektuplarıyla ateşkes çağrı mektubunu” içermektedir. Buna göre, diplomasi çevirisinde dilsel, kültürel, metinsel, ortam ve çevirmen açısından pek çok zorluk olduğu gözlemlenmiştir. Diplomatik metinlerin çevirisinde işlevsel çeviri yaklaşım benimsenip erek dil ve kültür odaklı çeviri yapılması, çevirmenin metin dili ve geleneklerine hâkim olarak diplomasinin her alanında çeviri yapabilme yeteneğine sahip olması beklenmektedir.

Anahtar kelimeler: Çeviri, diplomasi dili, diplomat, diplomatik metin türleri, çevirmen.

\section{Diplomacy language and translation}

\begin{abstract}
Diplomacy, which serves to establish relations between different societies, is defined as one of the foreign policy instruments of States. There are many types of diplomacy: old, new, ad hoc, continuous, secret, closed, open, etc. Today, diplomacy is carried out through diplomats. Diplomacy is a formal language, it has certain patterns. It is part of the political language. The language of diplomacy is divided into three categories: the language of expertise, technical terms and expressions and language of negotiation. There are many types of text, both written and spoken. Because diplomacy is the art of persuasion, it refers to the language's calling function. In the language of diplomacy rhetoric is encountered as metaphor, metonymy, antonomasia, analogy, litotes, euphemism, personification, triple string etc. The aim of this study is to examine the formal, semantic and cultural features of diplomacy, to determine the problems and translation strategies encountered in the translation of diplomacy. The method of the study is descriptive. In this context, the texts taken from the press releases of the Ministry of Foreign Affairs of the Republic of Turkey were examined in
\end{abstract}

1 Doç. Dr., Marmara Üniversitesi, Fen Edebiyat Fakültesi, Mütercim-Tercümanlık Bölümü, Fransızca MütercimTercümanlı ABD (İstanbul, Türkiye), gulhanim.unsal@marmara.edu.tr, ORCID ID: oooo-ooo1-7374-3575 [Makale kayıt tarihi: 07.11.2019-kabul tarihi: 20.12.2019; DOI: 10.29000/rumelide.656595] 
accordance with the decisions of the translator in the target language. The review texts include "condemnation letters with condolence letters written in the context of assault, accident, death". Accordingly, it has been observed that diplomatic translation has many difficulties in terms of linguistic, cultural, textual, environment and translator. It is expected that a functional translation approach will be adopted in the translation of diplomatic texts and that the translation will be focused on the target language and culture, and that the translator will be able to translate in all areas of diplomacy with a command of the text language and traditions.

Keywords: Translation, diplomatic language, diplomat, types of diplomatic text, translator.

\section{Giriş}

Diplomasi terimi Eski Yunanca «diploma»'dan gelir, «ikiye katlamak» anlamı taşır (Robert, 1986) ve XVIII. yüzyıla kadar da «belgeleri inceleme bilimi» olarak bilinir (Tuncer, 2005, s. 13).

Diplomasi terimi dil, din, ırk, gelenekler ve görenekler yönünden, birbirinden çok farklı topluluklar arasında ilişki kurmaya yarayan araçların başında gelir (Tuncer, 2005: 9). Diplomasi terimi, "dış politikanın içeriği; dış politikanın yürütülüş biçimi; görüşmeler yoluyla uluslararası ilişkilerin yürütülmesi; bağımsız devletlerin hükümetleri arasındaki resmi ilişkilerin yürütülmesinde uygulanan zekâ ve incelik (Tuncer, 2006, s. 15); Devletlerin dış politika araçlarından biri; geniş anlamda, bir devletin tüm dış ilişkilerini nitelerken, dar anlamda bir hükümetin belirli konulardaki kanı ve görüşlerinin, doğrudan doğruya diğer devletlerin karar alıcılarına iletilmesi süreci” olarak değişik biçimlerde tanımlanır (Sönmezoğlu, 1996; Gümüş ve Sevi, 1996). Diplomasi diyalog ve müzakereye ilişkindir ve bu anlamada sadece bir devlet aracı değil, devlet sisteminin bir kurumudur. Bir araç ve kurum olarak diplomasi, uluslararası ilişkilerin bütün bir mantığının temel parçasıdır (Evans ve Newnham, 2007, s.167). Dişişleri'nin aracı, «kariyer», «görev» ve «diplomatlar topluluğu», merkezi yönetim ve ağı olarak tanımlanır. Başkalarıyla iletişimde belli bir «sanat» izlenimi telkin ederek, temas ve beceri izleri taşıyarak, Devletler ile bireyler arasındaki davranışlara gönderme yapan (Villar, 2006, s. 12) bir terim, Devletlerarası görüşme sanatı (Lexique des Termes Juridiques, 2017) olarak betimlenir.

\subsection{Diplomasi türleri (types de diplomatie)}

Tuncer (2006, s. 23), diplomasiyi eski ve yeni olmak üzere ikiye ayırır. Eski diplomasi I. Dünya Savaşı'nın sonuna kadar uygulanan diplomasi yöntemidir. Bu diplomasi, hükümdarlar eliyle yürütülen «kişisel diplomasi» türüdür ve büyük ölçüde «gizli» niteliktedir. Diplomasinin gizli niteliği, eski diplomasiyi yenisinden ayıran en önemli özelliktir. I. Dünya Savaşı sonunda, dünyada ekonomik, teknolojik, bilimsel, tıbbi ve kültürel alanlarda devletlerarası işbirliği gereksiniminin büyük bir hızla ortaya çıkışı, «açık» nitelikte Yeni bir diplomasi anlayışı ortaya çıkarmıştır (Tuncer, 2006, s. 25). Demokrasi, iletişim ve basın «açık» diplomasiyle en güçlü bağı kurar. Diplomasi türleri şu şekilde sinıflandırlabilir:

-Ad hoc diplomasi (diplomatie ad hoc): Tarihte uygulanan ilk diplomasi yöntemi ad hoc nitelik taşır. Ad hoc diplomasi, tek-yanlı ve geçici bir diplomasi yöntemidir. İlk örnek olarak, eski Yunan kentdevletleri arasındaki diplomasi gösterilebilir. Bu yöntemde diplomatlar haberci niteliği taşır (Tuncer, 2006, s. 16).

-Sürekli diplomasi (diplomatie permanente): Ad hoc diplomasi yerini sürekli diplomasiye bırakmıştır. İlk kez XV. yüzyılda İtalyan kent-devletleri tarafından uygulanmıştır (Tuncer, 2006, s. 18). 
-Gizli diplomasi (diplomatie secrète): XVII. ve XIX. yüzyllda Avrupa diplomasisinde en belirgin özellik gizliliktir. Saray diplomasisi olarak da bilinir ve her aşaması dışa kapalı olarak yürütülür (Gümüş ve Sevi, 1996, s. 237).

-Kapalı diplomasi (diplomatie fermée): Bir diplomasi anlayışı ve uygulamasıdır. Gizlilik içinde yürütülür. Eski diplomasinin en önemli niteliklerinden biri gizliliktir (Gümüş ve Sevi, 1996, s. 251).

-Açlk diplomasi (diplomatie ouverte): Bu diplomasi anlayışında, diplomatik görüşmelerle ilgili tarafların yüklenecekleri hak ve sorumlulukların kamuoyunun bilgi ve denetimine sunmaları gerekir. Amaç, iki ya da daha fazla devletin aralarında gizlice anlaşarak, bir başka devletin temel hak ve yetkilerine yönelik bir eyleme hazırlanmalarını engellemeye çalışmaktır (Gümüş ve Sevi, 1996, s. 201).

XVIII. ve XIX. yüzyıl Avrupası'nda «altın çağını» yaşayan klasik diplomasi, çağımızda eski önemini kaybetmiş, buna karşılık bazı yeni diplomasi türleri ortaya çıkmıştır: İkili (diplomatie bilatérale), konferans (diplomatie de rencontre), çok-yanl ya da parlamenter (diplomatie multilatérale ou parlementaire), sessiz (diplomatie silencieuse), zirve ya da doruk (diplomatie de sommet, de pointe), koridor (diplomatie de corridor), mekik (diplomatie de la navette), insanî (diplomatie humanitaire), etki (diplomatie d’influence), uzaktan (e-diplomatie), dijital (diplomatie numérique) vb. (Sönmezoğlu, 1996; Gümüş ve Sevi, 1996; Tuncer, 2005, s. 91).

\subsection{Diplomat (diplomate)}

Diplomasi geleneği, Eski Yunan ve Roma'da, Eski Çin ve Hindistan'da elçi ve haberciler, sonraları hükümdarları temsilen aristokratlarca yürütülmüş̧tür. Günümüzde ise diplomatlar üzerinden yürütülmektedir. Diplomat terimi, "her ülkenin Dışişleri Bakanlığı bünyesinde kendi devletlerini uluslararası düzeydeki ilişkilerde temsil etmekle devlet tarafından resmi olarak görevlendirilmiş kişileri” tanımlamakta kullanılır (Sönmezoğlu, 1996; Gümüş ve Sevi, 1996). Aslında, hükümet temsilcisi ya da büyükelçi, insan toplumunda oluşturulan ilk siyasi rollerdendir. Rönesans döneminde bilgi edinmek, siyaset ve eğilimleri yorumlamak, askeri ve siyasi çıkarları korumak ve ticari bağlantıları iyileştirmek amaciyla dizgeli ve geniş ölçüde uzman diplomatik görev kurulmuştur (Evans ve Newnham, 2007, s.167). Diplomatik temsilciler 1815 'te Aix-la-Chapelle Kongresinde büyükelçiler, ortaelçiler, maslahat güzârlar ve yerleşmiş elçiler şeklinde sınıflandırılmıştır (Gümüş ve Sevi, 1996, s. 269).

Antik Yunan'da diplomatlar Tanrlarn habercisi olarak bilinen Hermes’in koruyuculuğu altınadır. Hermes, Tanrıların habercisi, ölenlerin ruhlarının elçisi ve yol göstericisi, hatiplerin, tüccarların, hırsızların Tanrısı (Estin ve Laporte, 2002, s. 99, 137); yarı Tanrı, yarı ölümlü, Tanrı ile ölümlüler arasında aracılık yapan ulak, yazı ve dilin kâşifi ve Tanrılara ölümlülerden getirdiği iletileri çeviren bir çevirmendir (Eruz, 2010, s. 164). O halde, antik çağdan beri, diplomatların seslerinin gürlüğünü, belleklerinin gücünü ve dil becerilerini, günümüzde "dokunulmazlığa” dönüşen kutsallhklarını Tanrı Hermes'ten aldıkları söylenebilir. Ayrıca, Herméneutique biliminin (yorumbilim) adını, iletileri yorumlayarak Tanrılara aktarmakla görevli olan Hermes’ten aldığı da ifade edilebilir. Ne var ki, tarihte diplomatlar yabancı, yalancı, onurlu casus, gölge adam, saray adamı, korkak, tavizci, donuk bürokrat gibi yakıştırmaların hedefi olmuştur (Villar, 2006, s. 107; Tuncer, 2006, s. 19; Yetkin Karakoç, 2015, s. 20).

Hotman de Villiers, 1604'de kaleme aldığı De la charge et dignité de l'ambassadeur (Büyükelçinin yükümlülükleri ve haysiyeti) adlı eserinde -en eski eserlerden biridir- "bir diplomatın hem tarih ve 
kültür bilgisinin, hem de kendini ifade etme yeteneğinin her şeyden önce geldiğini” söyler ve diplomatı «diğerleriyle iletişim kuran, kuram ile uygulamayı, geçmiş ile şimdiyi, deneyim, keşif ve kişisel uygulamayı, resmi değerlendirme, inceleme ve yansıtma kadar iyi bağlayan » biri olarak tanımlar (Hotman de Villiers, 2003, s. 20). Aynı anlayışla Baron d'Holbach (2010, s. 18), saray mensubunun ve monarşi karşısında zihinsel düzenlenişinin kemirici portresini, "rakiplerini uyutmayı, en çok nefret ettiği kişiye hoş, sevecen bir yüz göstermeyi, boğmak istediği düşmanını şefkatle kucaklamayı bilmek ve en ihtiyatsız yalanların dahi rakibin yüzünde hiçbir değişiklik yaratmamasını sağlamak gerekir" diyerek çizecektir. Öte yandan, arabuluculuktan çok görgüye, nezaket kurallarına yakın olan, kim olduğunu bilme ve davranma biçimleri büyükelçilerin belleğini oluşturur. Büyükelçiler az konuşur; bedensel davranış ile bireysel özgürlük dereceleri önem arz eder. Bu durum, mesleğin bağlam, biçim ve yapısının sözlü olduğu kadar sözsüz ifade biçimlerine de ne kadar bağlı olduğunun bir göstergesi sayılabilir. Kingston de Leusse (1998, s. 86), "göreve atandığı andan itibaren, büyükelçinin kendisini eylem, kıyafet, davranış, iletişim biçimi, ince ve barışçıl diplomatik görüşmelerinin bir özellik arz ettiği kapalı bir ortamda bulduğunu; öznel bir birey olarak silindiğini; dil ve kanıtlarına özen göstererek kendini ifade ettiğini; ülkesinin siyasi durumunu ve görgüsünü yansıttığını" ifade eder. Bunun yanında, diplomatın ağzı sıkı olmalı (Villar, 2006, s. 17), mümkün olduğu kadar muğlak, gerektiği kadar açık olmalıdır (Villar, 2006, s. 190). Ayrıca, 3 S kuralı -sabırlı, sakin ve soğukkanlı olmak- bir diplomatın sahip olması gereken vazgeçilmez nitelikleri arasında sayılabilir.

\subsection{Diplomasi dili (Langue diplomatique )}

Diplomasi dili hakkında siyasi dilin bir türü olarak kabul edilmesi dışında pek az şey söylenmiştir. Fransız diplomat Talleyrand (1754-1838)'a göre 'birçok şey, hiçbir şey yapmamakla yapılır' (Tuncer, 2005, s. 36). Diplomatlar «hiçbir şey söylememek» ya da «bir şeyleri saklamak» için konuşurlar ama «hiç bir şey söylemeden» konuşuyor olmakla eleştirilirler.

Geniş kitlelerce diplomasi, söze dayanan, şifreli ve biçimsel bir dil kullanan, güçlülerin yararına sır geliştiren, kendini gösterme sanatı olarak bilinir (Arifon, 2010, s. 72). Diplomasi dili, duruma göre sıradan, örtük, sağduyulu, gizli, ihtiyatlı, tamamlanmamış, yalan olarak nitelendirilir. Diplomatlar çelişik, zıt, yoğunlaştırılmış ve sözcük oyunlarıyla dolu tümcelerden çok hoşlanırlar (Villar, 2006, s. 17). Sıradanlık, örtüklük, muğlaklık, azaltma ve yalan diplomatik söylemin temel özelliği (Villar, 2006, s. 21) olarak kabul edilir. Villar (2006), Göstergebilimsel yaklaşımla diplomasi dilini /İçten x İkiyüzlü/ Doğru x Yalan/ Gerçek x Sahte/ Şeffaf x Sir/ olmak üzere dört eksene ayırır. Bu eksenlerden hareketle, söylem çözümlemesi çalışmalarıyla uyumlu olarak kullanılan diplomasi dilinin, bazı istisnai durumlar dışında, teknik bir söylem değil, doğal bir dil olduğu söylenebilir (Arifon, 2010, s. 72).

Berridge ve James (2001) diplomasi dilini; 1-uzmanlık dili; 2- teknik terim ve ifadeler; 3- müzakere dili olmak üzere üçe ayırır:

\section{Uzmanlk dili}

Herhangi bir tahriki en aza indirgemeyi amaçlayan ve gizli sezdirimlere bağlı örtmecelerin kullanıldığı «uzmanlık» dilidir. Bu dil diplomatlara özgü bir üslup içerir. Villar (2006, s. 42), uzmanlık dilini niteleyen beş özelliği şöyle açıklar: Dil olarak, somut, doğal, sözlü, ikna edici; uzmanlık dili olarak, günlük dilin bir alt-birimidir. Diplomasi dili yapay değil, doğal bir dildir. 


\section{Teknik terim ve ifadeler}

Diplomasi dilinin kendine özgü bir jargonu, bir takım kalıp söz ve deyimleri vardır: "Acte finale" (ninai sened), “acte hostile” (düşmanca hareket), "bons offices” (iyi niyet), "Chargé d'affaires” (maslahatgüzar), "compromis d'arbitrage" (tahkimname), "corps diplomatique" (diplomatlar birliği), "démarche" (girişim, başvurma), "proces-verbal” (tutanak), "prendre acte de" (saptamak, göz önünde tutmak), "daimi/fahri temsilcilik" (représantation permenante/d'honneur), “diplomatik valiz" (valise diplomatique), “diplomatik tavır" (attitude diplomatique), "diplomatik dokunulmazlık" (immunité diplomatique), "azizim" (mon cher), "arabulucu” (négociateur), "karşlıklı iş birliği çerçevesi” (cadre de coopération mutuelle), "ültimatom vermek" (donner un ultimatum), "büyükelçiyi geri çağırmak" (rappeler l'ambassadeur) “diplomat kızmaz, not alır” (un diplomate ne fâche pas, prend des notes) vb.

Ayrıca diplomasi dilinde sıklıkla, doğru ve yerinde kullanmak kadar yazılı çeviride doğru yazmanın, sözlü çeviride doğru sesletmenin uygun olacağı, Latince terimlere rastlanır: "Ad hoc” (uygun, gerekli), "ad libitum” (isteğe bağll), "ad referandum” (danışma koşullu imza, geçici onay), "casus belli” (savaş nedeni), "cine die" (belirsiz bir zamanda), "grosso modo" (genel hatlariyla), "sine qua non" (olmazsa olmaz şart), "ipso facto" (durum gereği), "in extenso" (bütün olarak), "intuitu personae" (kişiye bağll), "intra legem" (kanunlara uygun), "modus vivendi" (geçici anlaşma), "pacta sund servanda" (ahde vefa ilkesi), "persona non grata" (istenmeyen kişi), "statü quo" (mevcut durum), "ultimatom" (son uyarı), "vice versa” (karşılıklı olarak), "sui generis" (nevi şahsına münhasır), vb. (Akıncı, 1997, s. 106; Kıran ve Korkut, 2011, s. 222-223).

\section{Müzakere dili}

Belirli bir sürede, lingua franca'ya hizmet eden doğal dil, "resmi dil" ya da "müzakere dilidir." Lingua franca (geçer dil), uluslararası ortamlarda, farklı etno-dil kökenli insanlar arasındaki iletişim için kullanılan bir köprü dilidir (Villar, 2006, s. 107). Bu dil, diplomatik yazışmalarda ve diyaloglarda kullanılan dildir ve diplomasi dilinin iç boyutunu içerir.

Diplomasi çevirisi ilk devletlerin uluslararası ilişkileri ile başlar. Avrupa'da diplomasinin tam olarak kurumsallaşmadığı XVII. yüzyıla kadar Latince kullanılır. Saeed (1991, s. 28), uluslararası siyasi ilişkilerde tek dilsel araç olarak Latincenin hâkim olduğunu belirtir. Ancak daha sonra XVII. ve XVIII. yüzyllarda diplomasiye büyük ölçüde yön ve biçim veren Fransizlar olacak (Tuncer, 2006, s. 19) ve Latincenin yerini Fransızca alacaktır. Fransa'da ve XX. yüzyılın başına kadar diplomaside ve diğer idari işlerde kullanılan dil, köklerini saray dilinden, özellikle de 1643-1715 yılları arasında 72 yıl Fransa krallı̆̆ yapan, «Devlet, benim» «L'Etat, c'est moi» diyen Güneş Kral XIV. Louis (1638-1715)'den alır. Fumaroli (2003), sadece bu durumun dahi "diplomasi dili olarak Fransızcanın yerini açıkça ortaya koyduğunu” ifade eder. Dönemin Antlaşma ve Konferanslarında (1748 Aix-la-Chapelle, 1763 Versailles, 1815 Viyana, 1856 Paris) kullanılan dilin Fransızca olması diplomasi dili olarak Fransızcayı güçlendirecektir.

Dil yoluyla siyaset yapmak, siyasetin geçerli tek aracıdır (Aksoy, 2002, s. 4). Diplomasi de siyaset yapanların kullandıkları araçlardan biridir. Bu bakımdan, diplomasi dilinin uluslararası siyaset yapma niteliğini artırdığı söylenebilir. Diplomasi dili ile siyasi dili arasındaki ayrıma şöyle varılabilir:

-Siyaset dili, tüm somutlaştırma çabalarına karşın, soyuttur (Aksoy, 2002, s. 5). Bu durumun siyaset diline göre, günlük dil kullanımından daha uzak olan diplomasi dili için de geçerli olduğu söylenebilir. 
-Siyasiler gerçekten kopuk, önceden tasarlanmış, soruna yanıt vermeyen, hatta kasıtlı olarak tahrif edici, kötüye kullanmaya açık «kalıplaşmış dili» -langue de bois- kullanmakta ustadırlar (Arifon, 2010, s. 72). Siyasiler diplomasi dilinin uzlaşmacı yönü kullanıp ifade etmek istediklerini kararlı ve ince bir biçemde aktarirlar.

-Diplomasi dili, belirsiz ve geçici bir bağlamda ikna sanatı ve uğraşı olan siyaset dilinin bir parçasıdır ve amacı sürdürülebilir kanaati ortaya çıarmaktır. Ancak, 'siyasi dil yönetim dilinden ayrılır. Siyaset dili ikna edici, yönetim dili belli bir alanda davranmayı teşvik edicidir’ (Legrand, 2010, s. 27).

-Diplomasi dili kaçınma, muğlaklık, azaltma, renk vermeme, gizleme vb. bazı özelliklere sahiptir (Arifon, 2010, s. 72-73). Düşünce ve duyguların ifadesi, dilin eksikliğiyle sınırlıdır. Dil onu kullanana aittir; her zaman bir yanılma, hata, yer değiştirme ya da kayma, boşluk ya da eksiklikler vardır. Bu iki muhatap arasinda bir mesafe yaratır.

-Diplomasi dilinin hem iç -diplomatlar arası- hem de dış -kamuoyu ve medya- boyutu vardır.

-Diplomasi geniş ölçüde dil ve anlama dayalıdır. Diplomasi doğal dili kullanır ve özel bir düzgü (code) buna eşlik eder. Bu Devletlerarası ve birbirleriyle görüşmekle yükümlü bireyler arasındaki düzgüdür. Bu düzgünün ötesinde, söz ve duyguları azaltmak, indirgemek doğru olur. Bunun pek çok sebebi vardır (Arifon, 2010, s. 74):

1-Düzeyini korumak ve kendini tuttuğunu göstermek yerinde olur; bir anlaşmazlığı gülümseyerek ifade etmek en mükemmel resimdir.

2-Muhatabını incitmemek, gücendirmemek, ezmemek uygun olur; çünkü kızmak, hatta kesmek, diyalogu ya da görüşmeyi koparmakla sonuçlanabilir.

3-Diplomasinin kuralı tedbirdir. Bunun iki sebebi vardır: 1-Muhatabı incitmekten ve durum hakkında çok şey söylemekten kaçınmak gerekir; 2- Çok konuşmak görüşmenin iyi gidişatını bozabilir.

4-Zayıflık göstermekten kaçınmak doğru olur: Zayıflık, teknik konuda bilgi sahibi olmama ve itibarını ve simgesel gücünü koruma isteği olarak, ikiye ayrllabilir.

Görüldüğü gibi, diplomatik görüşme ve yazışmalarda kullanılan dil aşırılıklardan uzaktır. Bu uzaklık diplomatik söylemlerde biçimsel dil kullanıldığının (Villar, 2006, s.15) bir göstergesi sayılabilir. Biçimsel dilin ise 'sözcükleri tarafsız kullanma ve niteledikleri şeyi yumuşatmaya yarayan' diplomatik bir yararı olduğu söylenebilir (Arifon, 2010, s. 75).

Bundan başka, diplomasi dilinin örtüklük, açıklık, nezaket ve karşllıklılık üzerine kurulu olduğu söylenebilir. Örtük ifade ve sezdirimlerin diplomatik dilin bir gereği olduğunu vurgulayan Doğan (2018, s. 97-98), örtüklüğün diplomasinin sözlü metinlerinde, açıklığın ise yazılı metinlerinde bulunan bir özellik olduğunu ifade eder.

Örtüklük çokanlamlılıkla açıklanabilir. Çokanlamlılığın dilsel araçları ise belirsizlik, muğlaklık, karmaşıklık ve genellik olarak şöyle ifade edilebilir (Zhang, 2012; Doğan, 2017, s. 43; Doğan, 2018, s. 92-3; Yetkin Karakoç, 2015, s. 69-71): 
-Belirsizlik (ambiguïté), anlamın sözcük anlamlarının karışıklığından dolayı belirsiz olması durumudur. Bu belirsizlik ses, sözcük ya da sözdizimsel düzeyde olabilir.

-Muğlaklık (vague), anlamın belirsiz ve havada kalması, ayrıntıların ve sınırların belli olmaması durumu olarak açıklanabilir.

-Karmaşıklk (flou), belli bir özellik için, o özelliğe sahip olma ölçütlerinin belli olmaması, bulanık olmasi durumudur.

-Genellik (généralité), ayrıntı verilmeden genel ifade biçimleri kullanılır.

Görüldüğü gibi, diplomaside kasıtlı bir biçimde örtük ifadeler kullanılır. Diplomasinin iletişim edimlerinin çözümlenmesi için, belirsizlik kavramı esastır; çünkü örtüklük rolleri ve davranışları çözümlemeyi sağlar. Diplomatın yetilerinden birinin de, hareket alanına yer açmak için, bu belirsiz, muğlak, bulanık, karışık ifadeleri yorumlamak olduğu söylenebilir. Bir diplomat «evet» diyorsa, bu «belki»; «belki» diyorsa, bu «hayır» demektir; «hayır» diyorsa, bu bir diplomat değildir. İfade ediyor gibi göründükleri şeyin tersi anlamına gelen bazı adlandırmaların belirsizliği, açık ve kesin ifade biçimlerinin görünüşteki anlamını tersine çevirir (Villar, 2006, s. 16).

Her dilde açık ve örtük nezaket kuralları vardır. Diplomasi dili görgü ve nezaket kurallarına, -âdâb-ı muâşeret- göre işler. Bir saygı, bir incelik içerir. Diplomasi dili abartılı bir incelikle yapmacık olarak algllansa da, bu incelik bağlam içinde anlam kazanır ve vazgeçilmezdir. Bu incelik her sözcük ve söylem düzeyinde kendini gösterir. Biçimsel ve ölçünlü bir kullanım gerektiren hitap şekillerinde sıklıkla ortaya çıkar. Ör., Büyükelçiye üçüncü çoğul şahısla, “Zat-ı Alileri” ya da “Ekselansları” şeklinde hitap edilir.

Karşılıklılık (réciprocité) özelliği ise, üzerinde düşünerek ve seçerek yanıt verme anlamını barındırır. Diplomatik metinlerde her bir ögenin bir amaca hizmet ettiği ve her bir sözcük ve ifadenin önceden belirlendiği söylenebilir.

\subsection{Diplomasi dilinde söz sanatları}

Diplomasi dili, Jakobson'un tanımladığı dilin altı işlevinden en çok çağrı işlevine (fonction conative) ya da dilin yaptırma işlevine başvurur. Çünkü amaç alıcıyı etkilemek, ikna etmektir. Diplomaside ikna edicilik büyük bir rol oynar ve söz sanatları (belagat-réthorique) buna aracılık eder. Diplomasi dilinde sıklıkla kullanılan söz sanatlarının eğretileme, düzdeğişmece, kapsamlayış, dolaylama, benzetme, örtmece, arıksayış, kişileştirme, tekrir sanatının özel bir alanı olanı içeren üçlü dizem vb. olduğu gözlemlenir.

-Ĕ̆retileme (métaphore), düzdeğişmeceye karşıt olarak, dizisel bağlantılar düzleminde, ortak anlambirimcikler kapsadıklarından aralarında eşdeğerlik ilişkisi kurulan anlamlı öğelerden birini öbürü yerine ve karşılaştırma yapılmasını sağlayan sözcükleri (örn. gibi) kaldırarak kullanma sonucu oluşan değişmece (Vardar, 2002, s. 89-90) olarak tanımlanır. Örnekseme ve benzerlik üzerine kurulur, imgelemi özgürleştirir, niteliklerin aktarımıdır (Kıran ve Eziler Kıran, 2018, s. 459).

Eğretileme açı (métaphore in praesentia) ve kapalı (métaphore in absentia) olmak üzere iki şekilde yapılır (Ağıldere, 2003, s. 145-146). Siyasilerin amacı halka doğrudan ulaşmak olduğu için daha çok açı eğretilemeyi benimsedikleri söylenebilir. Türkçe kavramlaştırma, adlandırma sırasında doğaya dayanır, soyut kavramları somutlaştırarak dile getirir. Bunun için "imge gücü olan dil" olarak nitelendirilir 
(Aksan, 1996, s. 57). Dolayısıyla, soyut kavramların somutlaştırıldı̆̆ı, soyuttan somuta doğru yapılan eğretilemelere diplomasi dilinde de rastlamak mümkündür: "kukla hükümet", "söz milletin", "vergi cenneti", "dünya evimiz”, "enflasyon canavarı", “adil düzen”, "reis”, “demir leydi” vb. örnek olarak verilebilir. Ayrıca, eğretilemelerin siyasileri eleştiri ve sansürden kurtardığı da eklenebilir.

-Düzdeğişmece (métonymie), eğretilemeye karşıt olarak, tümcede dizimsel bir bağlantı kuran ya da belirtilen gerçeklik düzleminde yan yana bulunan öğelere ilişkin olarak, benzetme yapılmaksızın sonucun neden, kapsayanın kapsanan, bütünün parça, genelin özel, somut adın soyut kavram yerine kullanılması yoluyla oluşan değişmece (Vardar, 2002, s. 85-86) olarak tanımlanır. Örneğin, "İstanbul'u istiyorum" (İstanbul'da seçimleri kazanmak istiyorum), "Macron'dan Ankara'yı kızdıracak sözler!" (Türk Hükümeti), "Palais de l'Elysée" (Fransa Cumhurbaşkanı), Le Quai d'Orsay "Dışşsleri Bakanlı̆̆ı" vb.

-Kapsamlayış (sinécdoque), genel sözbilim "kapsamlayışı çoğu azla, azı çokla anlatan bir değişmece" olarak tanımlar (Kıran ve Eziler Kıran, 2018, s. 476). Özelleştirici ve genelleştirici (madde/nesne, tür/cins, tekil/çoğul ilişkiler, birey ve soyutlama kapsamlayışı) olarak ikiye ayrılır. Kapsamlayıştaki ilişkiler bağlam içinde anlaşılır. Örneğin, "Mavi bereliler" BM'de mavi bere giyen askerleri, "Bordo bereliler" Özel Kuvvetler Komutanlı̆ını, "Mehmetçik” Türk askerini kapsar.

-Dolaylama (antonomase), tek bir sözcükle ifade edilebilecek bir kavramı birçok sözcükle dile getirme yöntemi olarak kullanılan dolaylama, belirtilen nesnenin ya da kişinin doğasını, niteliklerinin ortaya koyar (Kıran ve Eziler Kıran, 2018, s. 480). Dolaylama gerçeği güzel ya da sert, kaba yapabilir. Ancak diplomasi dilinde daha ziyade güzelleştirdiği söylenebilir: Finlandiya "beyaz zambaklar ülkesi", Japonya "doğan güneş ülkesi”, Amerika "Yeni Dünya”, Fransa "Kilisenin büyük kızı", Antartika "beyaz cennet", Gabès "yeryüzü cenneti”, Paris "sşıklar şehri”, Roma "ölümsüz şehir”, XIV. Louis "GüneşKral”, Fransızca "Molière’in dili” vb. şeklinde dolaylama yapıldı̆̆ı görülür.

-Benzetme (comparasion), karşllaştırma, örnekseme yoluyla yapılan bir alımlama; bir varlığın özelliğini, başka bir varlığın ya da kavramın özelliğiyle anlatma biçimidir (Kıran ve Eziler Kıran, 2018, s. 459). Canlı benzetmeler akılda kalıcıdır. Bunun için, siyasiler imgelem gücünden yararlanarak benzetme sanatını sıklıkla kullanılır: "Limon gibi sıkılmak" deyimi ya da Çavuşoğlu'nun, "Fransa Cumhurbaşkanı Macron'un bugünkü konuşmalarını ayakları pislik içinde gömülüyken öten horoza benzetiyorum" (HaberTürk, 01.10.2019) tümcesi örnek olarak verilebilir.

-Arıksayış (litote), güçlü bir duyguyu yumuşatılmış, hafifletilmiş bir biçimde söze dökmektir (Kıran ve Eziler Kıran, 2018, s. 499). Örtüklük üzerine kurulu bir söz sanatıdır. Arıksayışta, gerçek düşündüğünden daha az şey söylenerek, söylemediğinden daha çok şeyin anlaşılması sağlanır. Arıksayış bazen abartmanın karşıtı olarak kullanılır. Ör, "yal" yerine "fakirhane", "yat" yerine "taka" vb. Ancak, siyasilerin daha ziyade yurt içinde abartma sanatını daha sıklıkla kullanırken, diplomatların arıksayış sanatını kullandığı dikkat çeker.

-Örtmece (euphémisme), dolaysız biçimde söylenmesi uygun görülmeyen bir olguyu örterek dolaylı yoldan anlatma (Vardar, 2002, s. 156) olarak tanımlanır. Diplomatik metin ve sözlerde sıkça kullanılan pek çok özdeyiş aşırı örtmeceyle vurgulanır. Böylece, «diplomasinin en çirkin şeyleri en zarif biçimde yapmak ve söylemek» olduğuna dair ortak bir kanı oluşur (Villar, 2006, s. 15). 
-Kişileştirme (personnification), nesne, hayvan, bitki, kavram gibi canlı ya da cansız, kişilikten yoksun varlıklara düzdeğişmece ya da eğretileme yoluyla kişilik vermek, onlara seslenme sanatıdır (Kıran ve Eziler Kıran, 2018, s. 502). Ör,. “Uluslararası Topluluk”, ‘ Birleşmiş Milletler’ vb.

- Üçlü dizem (rythme ternaire), yineleme (répétition) söz sanatının alt alanını oluşturan üçlü dizem peş peşe üç sözcüğün tekrar edilmesidir (Figures de Style, 2019). Bu söz sanatına "Liberté, Égalité, Fraternité”-Özgürlük, Eşitlik, Kardeşlik- örnek olarak verilebilir.

\subsection{Mizah}

Diplomatlar ve siyasiler yüksek iletişim becerisi sergileyen yaratacakları etkiyi ve kanaati ayarlamayı bilen iletişim uzmanlarıdır (Bulut, 2015, s. 41). İletişim becerileri zaman zaman mizah ile süslenir. Mizah siyasi söylemin bir parçasıdır. Örneğin, Avrupa Konseyi Parlamenter Meclisi (AKPM) Genel Kurulu'na hitap eden Başbakan Recep Tayyip Erdoğan, Fransız parlamenter Muriel Marland-Militelloya "Türkiye’ye çok Fransızsınzz" demesi (14.04.2011) mizaha bir örnek olarak verilebilir.

\subsection{Diplomatik metin türleri}

Genelde diplomatik metinler Kançlarya belgeleri ve Konsolosluk belgeleri olarak iki ana gruba ayrılır (Birleşmiş Milletler Sözlüğü, 2001, s. 123):

Kançlarya belgeleri, en yaygın yazışma türü olan Nota (Note Verbal); doğrudan ve gayriresmî diplomatik iletişim aracı olan, daha çok iyi niyet göstergesi için yazılan Mektup (Lettre); gayriresmî nitelikte, başlıksız ya da logosuz düz kâğıda yazılan Muhtıra (Non-Paper) olarak sınıflandırılabilir.

Konsolosluk belgeleri ise, oldukça çeşitlendirilmiş bir alandır; yasal ve yeminli çeviri alanlarıyla oldukça ilgilidir. Çok sayıda çeviri işi yaratır. Luque (1999, s. 2), "çevirmenlerin kendilerini doğum, ölüm ve evlenme belgeleri, engelsizlik belgesi, boşanma davaları, tapu, vize, pasaport, adli ölüm raporları, tutuklanan ülke vatandaşlarına yardım vb.” belgelerinin karşısında bulduğunu söyler.

Akıncı (1997, s. 107), yazılı diplomatik metinleri diplomatik yazışma ve doküman (belge, evrak) olarak ikiye ayırır. Günümüzde diplomaside hem yazılı hem de sözlü metinlerin önemini koruduğu söylenebilir. Bu bakımdan diplomatik metinler yazılı ve sözlü olarak ikiye ayrılabilir:

\section{Yazll diplomatik metinler}

- Nota: Dışişleri Bakanlığı'nın yabancı temsilciliğe ya da yabancı temsilciliğin Dışişleri Bakanlığı'na ya da diğer temsilciliklere yönelik resmi bir bildirimini içerir.

- Muhtıra: Büyükelçilik ya da diplomatik bir makam tarafından başlıksız kâğıda genelde Dışişleri Bakanlığı'na hitaben yazılan; belirli bir konuda, yazan tarafın görüş ve önerilerini içeren gayriresmî yazıları içerir (Luque 1999).

- Memorandum: Anlaşma ve sözleşme özetlerini içerir.

- Gayriresmî Belgeler: Resmi bir merci tarafından Büyükelçilik, Bakanlık, Genel Başkanlık vb. gayriresmî olarak yazılmış, makam başlığının kullanılmadığı yazışmaları içerir (Luque 1999). 
- Güven Mektubu: Büyükelçi tarafından ilgili devlet başkanına göreve başlaması sırasında sunulan mektubu içerir.

- Geri Çağırma Mektubu: Başka bir göreve atanmış Büyükelçi için, Büyükelçinin görevinin bittiğine ilişkin mektubu içerir.

- Atama Belgesi: Yurt dışına atamayla ilgili çeviriyle birlikte gönderilen belgeyi içerir.

- Buyrultu: Konsoloslara yönelik sadece Türkçe olarak, konsolosların atama mektuplarına dayanarak düzenlenen belgeyi içerir.

- Nihai Sened: Konferans sonunda kabul edileni gösteren belgeyi içerir (Akıncı, 1997, s. 107).

- Resmi yazılı sözleşmeler;

- Anlaşmalar [ekonomik (contrat), siyasi (traité), sosyal (accord ou convention) vb. alanda yapılan anlaşmalar];

- Protokol: Diplomatlar arasında yapılan anlaşma tutanağını içerir. Ek Protokol ise ek konular için düzenlenen tutană̆ 1 içerir.

- Ültimatom: Bir devletin başka bir devlete verdiği ve hiçbir tartışma veya karşı koymaya yer bırakmaksızın, tanıdığı sürede isteklerinin yerine getirilmesini istediği nota (TDK, 2005).

-Davet, Kutlama, Taziye mektuplar, vb.

\section{Sözlü diplomatik metinler}

Sözlü diplomatik metinler, özel, ikili ya da çoklu görüşmeler, beyanlar, söylemler, resmi toplantılarda "hoş geldin" ya da "veda" konuşmaları, basına açık konuşmalar, sosyal etkinliklerde açış konuşmaları vb. olarak belirlenebilir.

Her türlü iletişim biçiminin kasıtsız ve doğal bir ideolojik kılıfa büründüğü söylenebilir. Yazılı ya da sözlü bütün siyasi metinler taraf olan, taraftar arayan, belli bir görüşü savunan ve tarafsız olması gerekmeyen kişilerin ürettiği metinlerdir (Bulut, 2008, s. 65-66). Siyasi metinlerin bir yönünü oluşturan diplomatik metinler de ideolojik bir özellik taşır. Bunun için diplomatik dil, ortam ve metinler "hassasiyet" içerir. Bunun nedeni siyasi metinlerin:1- kasıtlı olarak yapılan bir değişiklikten; 2- fiili üretim ve müzakerelerde kullanımından; 3- ideolojik amaçlarla yorumlanmasından ileri gelebilir (Yetkin Karakoç, 2015, s. 56). Diplomatik metinlerin, üzerinde oynanmaya, kötüye kullanmaya ne kadar açlk olduğunun bir göstergesi olarak; "Suriye'de yürütülen Barış Pınarı Harekâtını içeren taslak metinde, duruma uygun düşen sözcüğün «durdurma, ara vermek » "suspend ya da pause" olduğu belirtildiği halde, kasıtlı olarak, İngilizcede "ateşkes » anlamına gelen "ceasefire" sözcügün kullanılması" örnek olarak verilebilir (Çelik, 2019). Siyasi ve diplomatik dil, dilsel içeriği açısından hassastır. Çünkü diplomasi dili de uzlaşma aracıyken siyasi dil yönlendirme aracıdır.

Diplomatik metinler ve çevirileri güvenlik ve gizlilik derecelerine göre; gizli olmayan (non-classifié); kapalı, gizli (classifié), özel, gizli (confidentiel), gizli (secret); çok gizli (top secret) olarak sinıflandırılabilir (Luque, 1999). 
Uluslararası haber çevirisinde sosyo-ekonomik (maliyet, iş hacmi vb.), sosyal (aracı, memnuniyet vb.), kültürel (ideoloji, değer, kısıtlama vb.), bilişsel (zihinsel süreç, karar alma, bilgi paylaşımı vb.) ve metinsel (okuma, çevirme, düzeltme aşamalarında kullanılan malzeme vb.) bağlamlara dikkat etmek gerekir (Gambier, 2010; Yetkin Karakoç, 2015, s. 131).

\section{7. Çalışmanın amacı}

$\mathrm{Bu}$ çalışmanın amacını, diplomasi dilinin biçimsel, anlamsal ve kültürel özelliklerini incelemek, diplomasi çevirisinde karşılaşılan sorunları ve çeviri stratejilerini belirlemek oluşturmaktadır.

\section{Yöntem}

Çalışma diplomasi dilinin özellikleri ve çevirisinde karşılaşılan sorunları ve çeviri stratejilerini belirlemek olduğundan çalışmanın yöntemi betimsel bir nitelik taşımaktadır. Bu bağlamda, T. C. Dışişleri Bakanlığı'nın basın bildirilerinden alınan metinler erek dilde çevirmen kararları doğrultusunda incelenmiştir. İnceleme metinleri "saldırı, kaza, vefat bağlamında yazılan taziye mektuplarıyla ateşkes çağrı mektubunu” içermektedir. Metinlerde diplomasi dili biçimsel, anlamsal ve kültürel açıdan incelenmiştir. Çeviri metinlerinin erek dil ve kültüre düz ve yananlamsal, metinsel, biçimsel ve edimsel düzeyde eşdeğerlilikleri araştırılmıştır.

\section{3. İnceleme}

Örnek 1: Fransızca-Türkçe

\begin{tabular}{l} 
No: 229, 1er Août 2o19, Communiqué de presse concernant les attaques perpétrées dans la \\
capitale temporaire du Yémen, Aden \\
\hline $\begin{array}{l}\text { Nous sommes profondément attristés d'apprendre que les attaques ayant visé les forces de sécurité dans la } \\
\text { capitale temporaire du Yémen, Aden, ont fait de nombreuses victimes et plusieurs blessés. }\end{array}$
\end{tabular}

Nous condamnons ces attaques, souhaitons la miséricorde divine à ceux ayant perdu la vie, un prompt rétablissement aux blessés, et transmettons également nos condoléances au gouvernement du Yémen et au peuple frère yéménite.

Il est inquiétant que la violence se poursuive sans relâche à un moment pendant lequel les efforts déployés par les Nations Unies pour trouver une solution politique à la crise au Yémen ont acquis une plus grande importance.

Nous espérons vivement que les affrontements entre les parties cessent, que les souffrances du peuple yéménite prennent fin de manière urgente et que la paix et la stabilité soient instaurées dans le pays.

No: 229, 1 Ă̆ustos 2019, Yemen'in Geçici Başkenti Aden'de Düzenlenen Saldırlar Hk.

Yemen’in geçici başkenti Aden'de güvenlik güçlerini hedef alan saldırılarda çok sayıda kişinin hayatını kaybettiği ve yaralandığı büyük üzüntüyle öğrenilmiştir.

Sözkonusu saldırıları kınıyor, hayatını kaybedenlere Allah'tan rahmet, Yemen Hükümeti’ne ve kardeş Yemen halkına başsağlığı, yaralananlara acil şifalar diliyoruz. 
Yemen'deki krize siyasi çözüm bulunması için BM öncülüğündeki çabaların daha da önem kazandığı bir süreçte şiddetin devam etmesi endişe vericidir.

Taraflar arasındaki çatışmaların durdurulması, Yemen halkının ıstırabının bir an önce son bulması, ülkede huzur ve istikrarın tesis edilmesi en büyük temennimizdir.

Metne yapısal olarak bakıldı̆̆ında dört bölümden oluştuğu görülür. Birinci bölümde olay, yani saldırı tanımlanmakta; ikinci bölümde olay kınanmakta ve bu yönde hisler dile getirilmekte; üçüncü bölümde mevcut siyasi duruma vurgu yapılmakta; son bölümde ise umut verici, iyi dilek ve temennilerde bulunma söz konusudur. Taziye iletilerin doğal, kaza ya da saldırı sonucu olmasına göre değiştiği görülür.

Kaynak metindeki "biz" şahsı yerine erek metinde "kişisiz" şahıs kullanıldı̆̆ı, eylem çatısının etken halden edilgen hale dönüştürüldüğü görülmektedir. Bu diplomatik görüme ve yazışmalarda kullanılan dilin aşırılıklardan uzak, tarafsız olma durumuyla açıklanabilir. Kaynak metin "illahi merhamet" (la miséricorde divine) "Allah’tan rahmet” şeklinde aktarılarak erek dil ve kültürde edimsel eşdeğerliği sağladığı, "temenni etmek" yerine "temenni” sözcüğü kullanılarak, fiili isimle değiştirme yoluna gidildiği, dolayısıyla değiştirme (transposition) stratejisinin kullanıldığı dikkat çekmektedir. Metinde geçen "kardeş, büyük üzüntü, endişe, ıstırap, şifa, huzur, istikrar" sözcüklerinin metne yoğun bir duygu değeri, duygusallık kattığı görülmektedir. Çünkü dil duyguya dayalı bir söylemdir. Bu söylemin de diplomasi dilinin soyutluğuna vurgu yaptı̆̆ı söylenebilir.

Örnek 2: Fransızca -Türkçe

No:221, 25 juillet 2019, Communiqué de presse concernant le décès de Béji Caïd Essebsi, Président de la République de Tunisie

Nous sommes profondément attristés par la nouvelle du décès du Président de la République de Tunisie, Béji

Caïd Essebsi. Nous souhaitons la miséricorde divine au défunt et transmettons nos condoléances au peuple ami et frère de la Tunisie.

Le Président Essebsi avait joué un rôle important dans la réussite de la transition politique de la Tunisie, basée sur la tolérance et la réconciliation, à la suite de la révolution de Jasmin et avait apporté une contribution inestimable à la démocratisation et à la stabilisation de la Tunisie.

L'ordre d'Etat lui ayant été conféré par le Président Erdoğan en 2017, le Président Essebsi a grandement contribué au renforcement de la coopération et de l'amitié dans toutes les sphères entre la Turquie et la Tunisie. Il restera à jamais gravé dans les mémoires avec affection et respect, comme un ami estimé de la Turquie.

No: 221, 25 Temmuz 2019, Tunus Cumhurbaşkant Beji Caid Essebsi'nin Vefat Hk.

Tunus Cumhurbaşkanı Beji Caid Essebsi'nin vefatından derin üzüntü duyuyor, merhuma Allah'tan rahmet, dost ve kardeş Tunus halkına başsağh̆ğı diliyoruz.

Sayın Essebsi Yasemin Devrimi’nin ardından Tunus’un siyasi geçiş sürecini hoşgörü ve uzlaşı temelinde başarıyla tamamlamasında önemli roller üstlenmiş, Tunus'un demokratikleşmesine ve istikrara kavuşturulmasına değerli katkılar sağlamıştır. 
2017 yılında Sayın Cumhurbaşkanımız tarafından devlet nişanı tevcih edilen Sayın Essebsi, Türkiye ile Tunus arasındaki dostluk ve işbirliğinin her alanda güçlenmesine de önemli katkıda bulunmuş olup, her zaman Türkiye’nin değerli bir dostu olarak sevgi ve saygıyla hatırlanacaktır.

Bu taziye mektubu yapısal olarak durum tespiti ve taziye; anma ve takdir etme; iyi dileklerde bulunma şeklinde üç bölümden oluşmaktadır.

Taziye mektubunda yoğun bir biçimde "demokratikleşme, istikrar, hoşgörü, uzlaşı, işbirliği, dostluk, kardeşlik, sevgi, saygı, derin üzüntü, değerli, devrim, hatırlama” vb. soyut kavramların kullanıldığı dikkat çekmektedir. Bu da öncelikle diplomasi dilinin soyutluğunun yanı sıra, ne kadar uzlaşmacı ve duygu yüklü bir dil olduğunun göstergesi sayllabilir. Söz sanatı olarak "ölüm” sözcüğü yerine "vefat" sözcüğü tercih edilerek örtmece sanatının yapıldı̆̆g görülmektedir. "Le Président” unvanının hitap şekli olarak "Sayın” biçiminde aktarıldı̆̆ , "Yasemin Devrimi”, "Devlet nişanı" gibi kültürel öğgelerin erek dilde edimsel eşdeğerliğinin gözetildiği, çevirisinde metin geleneklerine uyularak yerlileştirme stratejisinin uygulandığı söylenebilir.

\section{Örnek 3: Türkçe-Fransızca}

\begin{tabular}{|c|}
\hline Vo: 226, 30 Temmuz 2019, Pakistan'da Meydana Gelen Uçak Kazası Hk. \\
\hline $\begin{array}{l}\text { Pakistan’ın Rawalpindi şehrinde Pakistan Hava Kuvvetleri’nin eğitim uçuşu yapan bir askeri uçağının yerleşim } \\
\text { yerine düştüğü büyük üzüntüyle öğrenilmiştir. }\end{array}$ \\
\hline $\begin{array}{l}\text { Sözkonusu elim kazada hayatını kaybedenlere Allah’tan rahmet, yakınlarına ve dost Pakistan Hükümeti ile } \\
\text { kardeş Pakistan halkına başsağlığı diliyoruz. }\end{array}$ \\
\hline No: 226, 3o juillet 2o19, Communiqué de presse concernant l'accident d'avion au Pakistan. \\
\hline $\begin{array}{l}\text { Nous avons appris avec une profonde tristesse qu'un avion de la Force aérienne du Pakistan en mission } \\
\text { d'entraînement s'est écrasé dans un quartier résidentiel de la ville de Rawalpindi au Pakistan. }\end{array}$ \\
\hline $\begin{array}{l}\text { Nous souhaitons la miséricorde divine à ceux ayant perdu la vie dans cet accident tragique et transmettons nos } \\
\text { condoléances au gouvernement ami du Pakistan et au peuple frère pakistanais. }\end{array}$ \\
\hline
\end{tabular}

$\mathrm{Bu}$ taziye mektubu yapısal olarak, durum tespiti ve taziye ile iyi dileklerde bulunma şeklinde iki bölümden oluşmaktadır.

Kaynak metindeki "kişisiz" şahıs yerine, erek metinde "biz" şahsının kullanıldığı, edilgen eylem çatısının etken eylem çatısına dönüştüğü görülmektedir. Kaynak metinde "Allah’tan rahmet” dilemek ifadesi erek metne "la miséricorde divine" "İlahi merhamet" anlamında aktarılarak erek dil ve kültürde edimsel eşdeğerliğin sağlandı̆̆ı; işlevsel çeviri yaklaşımının benimsendiği görülmektedir. Erek metinde geçen “ami (dost), frère (kardeş), une profonde tristesse (büyük üzüntü), tragique (elem)” vb. sözcüklerinin diplomasi dilinin soyutluğuna gönderme yaparken metne bir duygu değeri, bir duygusallık kattığı, ince ve barışçı ifade biçimleriyle diplomasi dilinin hassasiyetini öne çıkardığı söylenebilir.

\section{Örnek 4: Türkçe-Fransızca}

No: 241, 10 Ă̆ustos 2019, Libya'da Kurban Bayramı Vesilesiyle Çatışmalara Ara Verilmesi Çağrısı Hk. 
Birleşmiş Milletler Genel Sekreteri Libya Özel Temsilcisi Salame’nin Kurban Bayramı vesilesiyle yaptığı çatışmalara ara verilmesi çağrısını destekliyoruz.

Libya Ulusal Mutabakat Hükümeti'nin insani mülahazalarla bu çağrıyı kabul etmesini memnuniyetle karşılıyoruz.

Birleşmiş Milletler Genel Sekreteri Libya Özel Temsilcisi'nin çabalarına destek veren Türkiye, tüm uluslararası camianın da bu hususta ortak tutum ve kararlılık sergilemesini beklemektedir.

No: 241, 10 août 2019, Communiqué de presse concernant l'appel à la trêve en Libye à l'occasion de l'Ä̈d Al-Adha.

Nous soutenons l'appel à la trêve lancé par le Représentant spécial du Secrétaire général des Nations Unies pour la Libye, Ghassan Salamé.

Nous nous félicitons de la décision du Gouvernement libyen d'entente nationale d'accepter cet appel pour des raisons humanitaires.

La Turquie soutient les efforts du Représentant spécial du Secrétaire général des Nations Unies pour la Libye et attend de la communauté internationale qu'elle adopte une position unie et résolue sur cette question.

Bu ateşkes mektubu yapısal olarak durum tespiti, çağrı ve iyi niyet dilekleri bölümlerini içeren üç bölümden oluşmaktadır.

Kaynak metinde "Kurban Bayramı vesilesiyle" ifadesi erek metinde eksiltildiği, çıkarma stratejisinin kullanıldığı; "Türkiye (...) beklemektedir" ifadesiyle genelleştirme yapıldığı ve aynı zamanda kapsamlayış sanatının kullanıldığı görülmektedir. Nous nous félicitons (kutluyoruz) ifadesinin “memnuniyetle karşılıyoruz” şeklinde erek dile aktarıldığı ve edimsel eşdeğerlik sağlandığı söylenebilir.

\section{Tartışma}

Teknik çeviri kapsamına giren en eski çeviri türü olarak bilinen diplomasi çevirisinde dilsel, kültürel, metinsel, ortamsal ve çevirmen açısından bir takım zorlukların üstesinden gelmek gerektiği konusu tartışmaya açılabilir.

\section{1-Dilsel açıdan}

Diplomasi dilinin yazıll, sözlü ve sözsüz dil biçimleriyle, her bir alana özgü teknik terim ve kavramlarıyla, kalıplaşmış ifade ve sözcük seçimiyle pek çok zorluk içerdiği görülür. Lardeux (2019, s. 1), kültürel, sosyal ve tarihsel gönderimlerden başka, bir ruh ve kader birliğine ait olma duygusunu yüceltmek için milli-milliyetçi söylemde daha da fazla yaratılan- siyasi söylemde bulunan çağrışım ve örtüklüğü çevirmenin her zaman kolay olmadığını ifade eder. Bu tür söylemlerde kullanılan terimlerin değişken, bazen kaygan, hatta belirsiz nitelikte olması çevirisini de bir o kadar zorlaştırır. Siyaset dili çevirisi açısından en temel zorluk, siyasi söylemin içerdiği soyut dil kullanımının bir işleve yönelik olması ve bu şekliyle kültürel ve anlamsal bağlamda çeviride daha da soyut bir hale dönüşmesi (Aksoy, 2002, s. 5) tehlikesinin diplomasi dili için de geçerli olduğu söylenebilir (Vural, 2007, s. 54). Ayrıca, diplomatik jargon, terim ve ifadeleri doğru ve yerinde kullanmak, doğru sesletim ve doğru çevirmek gerektiği vurgulanabilir. 


\section{2-Kültürel açıdan}

Her bireyin dil ve söylem biçimi onun kişiliğini ortaya koyar. Diller açısından da durum böyledir. Humboldtçu bakış açısına göre, 'ayrı ayrı dillerin sözcükleri aynı kavramı gösterseler dahi, hiçbir zaman gerçek eşanlamlı değillerdir.' Her dilde özel bir dünya görüşü vardır. Dillerin çeşitli oluşları yalnızca onlardaki ögelerin, göstergelerin, seslerin çeşitli olmasından değil, dünya görüşlerinin çeşitliliğinden kaynaklanır. Bu durum, dillere ayrı bir karakter verir ve onları çeşitli yapar (Cassirer, 1989: 41). Örneğin, her dilin aynı olayı sözdizimsel açıdan bile yapılandırış biçimi farklıdır. Burada çevirmenin asıl güçlüğü terim bilgisi değil, kültüre göre kendini ifade ediş biçimlerinin kavranıp diğer kültürde anlamlı olacak biçimde ve kaynak kültür özelliklerini de yitirmeden aktarılabilmesidir. Bu zorluk sözlü çeviride daha da kendini gösterebilir. Konuşma ve anında çeviri akışı sırasında anlık karar verme süreçleriyle gerçekleştirmesi oldukça zor görünmektedir (Doğan, 2018, s. 97-8).

Hitap şekilleri diplomasi dilinde çok önemli bir yere sahiptir. Yücelik, hayranlık ve saygı ifadesi olarak kullanılır. Dilimizde ikinci tekil kişiye hitap edildiği halde, üçüncü çoğul şahıs ekiyle kullanılır: Majesteleri (votre Majesté), Ekselansları (votre Excellence), Hazretleri (votre Altesse) vb. Hitap çevirilerinde erek kültür göz önünde bulundurularak metin geleneklerine ve edimsel eşdeğerliğe dikkat etmek çok yerinde olacaktır.

Eğretileme, düzdeğişmece, benzetme sanatlarının çevirisinde bilişsel-dilbilimsel yaklaşım kullanılabilir. Böylece metindeki ideolojiye, ilgili kültürün bilişsel şemalarına ve söylemi belirleyen sosyo-politik çerçeveye dair çıkarımlarda bulunulabilir (Yetkin Karakoç, 2015, s. 62-63). Arıksayış sanatının çevirisinde, bir duyguyu yumuşatma, azaltma bakımında erek metin kaynak metin düzeyleri birbirine yakın olmalı, çeviri metnin daha da aza indirgenmemesi uygun olur. Örtmecelerin çevirisinde, siyasi ve kültürel açılımlara; kişileştirme sanatının çevirisinde metindeki kişisel özelliklerin yananlamlarına ve erek metinde aynı etkiyi yaratmasına dikkat edilmelidir. Üçlü dizemler ses benzerliğine dayanıyorsa, çevirisinde bu benzerliği yakalamak kolay olmayabilir. Bu durumda özgün üçlü dizem için dipnot olarak bir açıklama yapılabilir.

Sözlü çevirilerde mizahi ögelerin, kültürel ifadelerin aktarımı anında yapılır. Zaman darlığı çevirmeni kısıtlar. Bu kısıtlama nedeniyle bir zorluk olabilir. Örneğin sözlü çeviride zamanla yarışan çevirmenin "Fransız kalmak" deyiminin Fransızca karşıllğını "Çinli kalmak" (être Chinois au) olarak hatırlayamaması sıkıntı yaratabilir. Görüldüğü gibi, mizahi ögeler, kalıp sözler farklı dillerde, farklı göstergelerle aktarılır. Bu durumda, bağlama ve duruma göre anlamları yansitılabilir ya da erek kültürde anlam ya da işlevini karşılayan bir ifadeyle aktarılabilir.

\section{3-Metinsel açıdan}

Çeviri sürecinde ise alınan kararlarda ideolojik bakış açısı ve konumlanmanın önemi ortaya çıar. Hem kaynak hem de erek metin ideolojik oynamalara açıtır. Çeviride metnin ideolojik boyutunun korunması gerekir. Ancak, metnin çok gizli (top secret) olması nedeniyle çevirmen metne nadiren ulaşabilir. Uluslararası haber çevirisinde sosyo-ekonomik, sosyal, kültürel, bilişsel ve metinsel bağlamlara dikkat etmek, her diplomatik metin türünü kendine özgü geleneğiyle çevirmek uygun olacaktır. Diplomatik metin türlerinin çevirisinde, sadece içerik aktarımının yeterli olmayacağı, metin geleneğiyle beraber biçimsel ve işlevsel eşdeğerliğin sağlanması gerektiği söylenebilir. Bunun için anlam ya da içerik aktarımında kaynak odaklı yaklaşım benimsenirken, biçimsel ve kültürel aktarım için erek odaklı yaklaşımın benimsenebilir. 


\section{4-Ortam Açısından}

Diplomatik konuşmaların tamamı resmi bir diplomatik ortamda geçmeyebilir. Örneğin, bir 'veda' yemeğinde, işlevsel söylemle, diplomat (işveren) Skopos'unu belirler. Konuşmasının tamamını değil de, özetinin çevirisi olarak belirlediği durumda, çevirmen, çeviriyi bu doğrultuda yapar. Burada, çevirmenden beklenen çeviri öncesinde diplomatik ortam, konu ve çevirisini yapacağı kişiyi tanımak olacaktır. Bunun için, çevirmene mümkün olduğunca ortama erken gitmesi, nerede duracağını belirlemesi, varsa mikrofon düzeneğini kontrol etmesi, çevirisi yapılacak kişi/kişilerle konuşarak şive ve konuşma tarzına aşina olması, ortama uygun şekilde giyinmesi, jest ve mimiklerinin abartısız olmasına dikkat etmesi vb. önerilebilir.

\section{5-Çevirmen açısından}

Çevirmenden dilsel ve kültürel zorluklarla başa çıkma yeterliliğinin yanı sıra, askeri, siyasi, iktisadi, hukuki, güvenlik vb. çok çeşitli alanlarda bilgi sahibi olması beklenir. Özellikle yazılı metinlerin hassasiyet ve bağlayıcılık arz etmesinden dolayı, çevirmenin çevirileri çok büyük bir titizlikle yapılması, en azından çeviriye başlamadan önce konu hakkında bir ön araştırma yapması, yaptığı çevirileri bir uzmana ya da varsa çeviri komisyonuna göstermesi önerilebilir. Öyleyse, çeviriye ortak müdahaleden bahsedilebilir. Bu durumda, çevirmen kimliğinden, varlığından söz etmek pek mümkün görünmüyor. Meslek etiği bakımından tarafsızlık, güvenilirlik önemini her zaman korumaktadır. Bunun nedenle çevirmeni denetleme gereği duyulmaktadır. Ancak bazı diplomatik ortamlarda, çevirmen taraflılığından -iyi niyetli olarak- söz edilebilir.

\section{Sonuç}

Bu makalede, T.C. Dışişleri Bakanlığı'nın basın bildirilerinden alınan "taziye mektuplarıyla ateşkes çağrı mektubu" hem kaynak dil hem de erek dil üzerinden çevirmen kararları doğrultusunda incelenmiştir. Bu bağlamda, diplomasi dilinin genel özellikleri biçimsel, anlamsal ve kültürel açıdan irdelenmiştir. Kaynak metnin erek dil ve kültüre düzanlamsal, yananlamsal, metinsel, biçimsel ve edimsel bakımdan eşdeğerliği araştırılmıştır.

Araştırma sonucunda elde edilen bulgulara göre, bilgilendirme amaçlı yazılan basın bildirilerinin yazılı dilin biçimci, kuralcı, açık olma gibi özelliğini taşırken diplomatik dilin resmi, tarafsız, soyut, duygu yüklü ince yönünü de ihmal etmediği; kaynak metinlerin erek dil ve kültüre metnin nesnel konusuyla metin dışı göndergesel anlama ilişkin çeviride en yerleşik, en temel, en yaygın anlamın kullanılması bakımından düzanlamsal; bir sözcüğün dile getirdiği duygu, çağrışım, biçem, doğal dilde kullanım sıklığı vb. bakımından yananlamsal; metin türü ve geleneği bakımından metinsel; söz sanatları, söz oyunları, mizah, deyim, imge vb. bakımından biçimsel; ülke, kültür, davranış biçimi, gelenek görenek vb. bakımından edimsel düzeyde eşdeğerliği sağladığı ve işlevsel bir çeviri yaklaşımı benimsediği söylenebilir.

Çevirmene, her ülke farklı işleyişe sahip olduğuna göre, o dilin konuşulduğu ülkeyi tanıması, kurum ve kuruluşların yapısını öğrenmesi, ülkelerarası kültürel farklılıkları, toplumsal değerleri göz önünde bulundurması, diplomasi dilinin bütün özelliklerini yansıtır nitelikte çeviri yapması önerilebilir.

Son söz olarak, "çevirmen elçidir; elçiye zeval olmaz" sözünden yola çıarak diplomaside "çevirmen elçinin de elçisidir; hata yapması durumunda "elçiye zeval olur" diyebiliriz. 


\section{Kaynakça}

Ağıldere, S. (2003). Siyasi Söylemde Eğretileme ve Düzdeğişmece. A. (Eziler) Kıran, E. Korkut, S. Ağıldere (yay. haz.), Günümüz Dilbilim Çalışmaları (s.143-155). İstanbul: Multilingual.

Akıncı, Z. (1997). Diplomatik Dil ve Özellikleri. TÖMER Çeviri Dergisi, Özel Kuram Sayısı, 105-112.

Aksan, D. (1996). Türkçenin Sözvarlı̆̆ı. Ankara: Engin.

Aksoy, N. B. (2002). Siyaset Dili ve Çevirisi. Hacettepe Üniversitesi Edebiyat Fakültesi Dergisi, Cilt (19) 1, 1-10.

Arifon, O. (2010). Langue diplomatique et langage formel: un code à double entente. In Hermès, La Revue, 3 (58), s. 69 - 78. Erişim Adresi:https://www.cairn.info/revue-hermes-la-revue-2010-3page-69.htm. (04.07.2019). DOI : 10.4267/2042/38676

Berridge, G.- James-A. (2001). A Dictionary of Diplomacy. University of the West of England, Bristol: Palgrave.

Bulut, A. (2008). Basından Örneklerle Çeviride İdeoloji - İdeolojik Çeviri. İstanbul: Multilingual.

Bulut, A. K. (2015). Tercüme Hatası!?. İstanbul: Çeviribilim.

Cassirer, E. (1989). Essais sur le Langage. Paris: Minuit.

Çelik H. (18.10.2019). CNN TÜRK, Erişim Adresi: https://www.youtube.com/watch?v=9vqbJArwYLM (20.10.2019).

Doğan, A. (2018). Sözlü Çeviride Diplomatik Söylem Parametreleri. E. Diriker (yay.haz.), Türkiye'de Sözlü Çeviri: Eğitim, Uygulama ve Araştırmalar (s. 85-112). İstanbul: Scala.

Doğan, A. (2017). Interpreting in Diplomatic Contexts. In A. Angı (Ed.), Translating and Interpreting Specific Fields: Current Practices in Turkey. (pp. 19-51). Frankfurt: Peter Lang.

Delporte, C., (2009). Une histoire de la langue de bois. Paris: Flammarion.

D’Holbach, Baron- P.-H. (2010). Essai sur l'art de ramper à l'usage des courtisans. Paris: Allia, Erişim Adresi: https://www.editions-allia.com/fr/livre/85/essai-sur-lart-de-ramper-a-lusage-descourtisans (07.07.2019).

Eruz, S. (2010). Çokkültürlülük ve Çeviri: Osmanh Devletïnde Çeviri Etkinliği ve Çevirmenler. İstanbul: Multilingual.

Estin, C. ve Laporte, H. (2002). Yunan ve Roma Mitolojisi. Çev. Musa Eran, Ankara: Tübitak.

Evans, G.-Newnham, J. (2007). Uluslararası İlişkiler Sözlüğ̈̈. Çev. H. Ahsen Utku, İstanbul: Gökkubbe.

Figures de Style, (2019). www.hugoetbalzac.fr/blog/les-figures-de-style.html (17.07.2019).

Fumaroli, M., (2003). Quand l'Europe parlait français. Paris: Le Livre de Poche.

Gambier, Y. (2010). Public Communications: Beyond Boundaries. C. Schäffner ve S. Bassnett (Eds.), Political Discourse, Media and Translation (s. 233-243). GBR: Cambridge Scholars Publishing. Erişim Adresi: https://www.cambridgescholars.com/download/sample/60006 (28.07.2019).

Gümüs, O.- Sevi, A. (1996). Uluslararası İlişkiler Sözlüğü. Ankara: Polat.

Habertürk: "Haberler-Gündem". (01.10.2019). https://www.haberturk.com/bakan-cavusoglu-macronayaklara-pislik-icinde-iken-oten-horoza-benziyor-2527069 (15.10.2019).

Hotman de Villiers, J., (2003). De la charge et dignité de l'ambassadeur. Paris-Cergy: Essec- Iréné.

Kıran, A. ve Korkut, E. (2011). Fransızca Sözcük Bilgisi. Ankara: Seçkin.

Kıran, Z. ve Eziler Kıran, A. (2018). Dilbilime Giriş. Ankara: Seçkin.

Kingston de Leusse, M., (1998). Diplomatie. Une sociologie des ambassadeurs. Paris: L'Harmattan. 
Lardeux, A. S. (2019). Discours politique et récit national, Quand la politique s'en mêle. Traduire, s.1523. Erişim Adresi: https://journals.openedition.org/traduire/1640 (14.07.2019).

Legrand, T., (2010). Ce n'est rien qu'un président qui nous fait perdre notre temps. Paris: Stock.

Lexique des Termes Juridiques (2017). 25. édition 2017-2018. S. Guinchard (Ed.).Paris: Dalloz.

Luque, A. F. (1999). An approach to Diplomatic Translation. Translation, 3 (4), https://translationjournal.net/journal/1odipl.htm (24.07.2019).

Robert, P. (1986). Le Petit Robert, Dictionnaire de la Langue Française. Paris: Le Robert.

Saeed A. (1991). Approaches to the Diplomatic Writings. Baghdad, Iraq: Publications of the Iraqi Foreign Service Institute.

Sönmezoğlu, F. (1996). Uluslararası İlişkiler Sözlüğü. İstanbul: Der.

T.C. Dışişleri Bakanlığı: http://www.mfa.gov.tr/no_229_-yemen-in-gecici-baskenti-aden-deduzenlenen-saldirilar-hk.tr.mfa (02.08.2019).

T.C. Dışişleri Bakanlı̆̆g: http://www.mfa.gov.tr/no_221_-tunus-cb-beji-caid-essebsi-nin-vefatihk.fr.mfa (02.08.2019).

T.C. Dışişleri Bakanlığı: http://www.mfa.gov.tr/no_241_-libya-da-kurban-vesilesiyle-catismalara-araverilmesi-hk.fr.mfa (11.08.2019).

T.C. Dışişleri Bakanlığı: http://www.mfa.gov.tr/no_226_-pakistan-da-meydana-gelen-ucak-kazasihk.tr.mfa (02.08.2019).

Tuncer, H. (2005). “Eski” ve "Yeni” Diplomasi. Ankara: Ümit.

Tuncer, H. (2006). Küresel Diplomasi. Ankara: Ümit.

'Türkiye'ye çok Fransızsınız' (14.04.2011). CNN TÜRK, Erişim adresi: http://www.radikal.com.tr/politika/turkiyeye-cok-fransizsiniz-1046114/ (20.10.2019)

Türkçe Sözlük (2005). 10. Baskı. Ankara: TDK.

United Nations Dictionary (2001). (10th ed.). New York: UNs Publications.

Vardar, B. (2002). Açılamah Dilbilim Terimleri Sözlüğü. İstanbul: Multilingual.

Villar, C., (2006). Le Discours diplomatique. Paris: L'Harmattan.

Vural Kara, S. (2007). Diplomasi Metinleri Çevirisi Örneğinde Kaynak Metin - Erek Metin Bağıntısı. Dil ve Edebiyat Dergisi. Sayı: 4 (1), 49-67.

Yetkin Karakoç, N. (2015). Çeviri ve Diplomasi. İstanbul: Çeviribilim.

Zhang, J. (2012). From interpersonal to international: two types of translation in the making of implicitness in diplomatic discourse. Perspectives: Studies in Translatology , 22(1), 75-95. 